\title{
GÉRALDINE TONIUTTI, Mise en recueil et assemblage des contraires. "Cristal et Clarie", "D'Amour" et le manuscrit Arsenal 3516
}

\section{Maria Colombo Timelli}

\section{(2) OpenEdition}

\section{Journals}

\section{Édition électronique}

URL : http://journals.openedition.org/studifrancesi/14913

DOI : 10.4000/studifrancesi. 14913

ISSN : 2427-5856

\section{Éditeur}

Rosenberg \& Sellier

\section{Édition imprimée}

Date de publication : 1 décembre 2018

Pagination : 474

ISSN : 0039-2944

\section{Référence électronique}

Maria Colombo Timelli, « GÉRALDInE toniutTI, Mise en recueil et assemblage des contraires. "Cristal et Clarie", "D'Amour" et le manuscrit Arsenal 3516 », Studi Francesi [En ligne], 186 (LXII | III) | 2018, mis en ligne le 01 janvier 2019, consulté le 07 janvier 2021. URL : http://journals.openedition.org/studifrancesi/14913 : DOI : https://doi.org/10.4000/studifrancesi.14913

Ce document a été généré automatiquement le 7 janvier 2021.

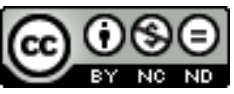

Studi Francesi è distribuita con Licenza Creative Commons Attribuzione - Non commerciale - Non opere derivate 4.0 Internazionale. 


\title{
GÉRALDINE TONIUTTI, Mise en recueil et assemblage des contraires. "Cristal et Clarie", "D'Amour" et le manuscrit Arsenal 3516
}

\author{
Maria Colombo Timelli
}

\section{RÉFÉRENCE}

GÉRALDINE TONIUTTI, Mise en recueil et assemblage des contraires. "Cristal et Clarie", "D'Amour" et le manuscrit Arsenal 3516, «Le Moyen Âge», CXXIII/2, 2017, pp. 339-349.

L'auteur anonyme de Cristal et Clarie, on le sait, fonde sa technique de composition sur des emprunts massifs à d'autres récits des $\mathrm{XII}^{\mathrm{e}}$ et XIII ${ }^{\mathrm{e}}$ siècle (emprunts pour lesquels G.T. adopte le terme d'《implicitation»); entre autres sources, il exploite le D'Amour de Robert de Blois (353 vers au total) qu'il cite entièrement dans son prologue. G.T. se concentre sur le manuscrit recueil Arsenal 3516, qui constitue non seulement l'unique témoin de Cristal et Clarie, mais qui contient aussi, à quelques feuillets de distance seulement, le D'Amour: elle montre bien la parenté entre les deux textes, malgré la présence de quelques variantes. Son étude confirme par ailleurs aussi l'intérêt de Cristal et Clarie pour l'établissement du stemma des œuvres citées par son auteur (Lai de Narcisse, Partonopeu de Blois, Athis et Prophilias entre autres). Elle conclut enfin sur le rapport entre le manuscrit de l'Arsenal, dont la dimension didactique ne fait pas de doute, et Cristal et Clarie, qui ferait basculer, de par son sujet même, du sérieux des textes de la première partie à la tonalité toute différente des dernières œuvres qui le composent, nettement marquées par la parodie (Lai d'Aristote et Lai du trot). Cette coprésence du sérieux et du burlesque illustre bien la tolérance du public médiéval à l'égard du «mélange des genres et des matières», ainsi que la nécessité de lire chaque 
œuvre médiévale «dans un ensemble, côte à côte avec d'autres écrits avec lesquels elle entre en dialogue» (p. 349). 